\title{
Islamic Values of Sura Ceremony Done by Samin People in Jepang, Margomulyo, Bojonegoro as Character Education for Undergraduates
}

\author{
Nur Alfin Hidayati', Herman J. Waluyo ${ }^{2}$, Retno Winarni ${ }^{3}$, Suyitno ${ }^{4}$ \\ \{nikidanajwasalsabila@gmail.com¹, herman.jwaluyo@yahoo.co.id²,winarniuns@yahoo.com³, \\ yitsuyitno52@gmail.com $\left.{ }^{4}\right\}$ \\ 1,2,3,4 Universitas Sebelas Maret, Indonesia \\ ${ }^{1}$ Lecturer of IKIP PGRI Bojonegoro, Indonesia
}

\begin{abstract}
The aims of this research are to describe: (1) the practices, (2) the intentions, and (3) the Islamic values of Sura ceremony done by Samin people in Jepang, Margomulyo, Bojonegoro. This research was considered as descriptive qualitative research. The data were collected through observation, interview, and document analysis. The object of the research was religious values found in Sura ceremony done by Samin people in Jepang, Margomulyo, Bojonegoro. The data were analyzed by using descriptive qualitative and interactive technique. The research findings show that Sura ceremony is a representation of Islamic piety since the people pray and hold selamatan aimed to share with others. It means that Sura ceremony nurtures relationship either among people or between people with their God. Sura ceremony has certain intentions. It comprises religious values as it teaches people to show gratitude for the life given by God, pray for protection, and share with others. Therefore, Sura ceremony is indeed suitable to be used as character education source implemented in higher education.
\end{abstract}

Keywords: Value, Islam, Sura Ceremony, Samin, Character

\section{INTRODUCTION}

Sura ceremony is a kind of selamatan done in the month of Sura that has significant and intentional meaning. It is done to show gratitude for the bounty given by the God to Samin people and elder [1]. The word sura comes from the word Asyura while Asyura itself is adopted from Arabic word 'Asyara that means ten. In a context of Islamic Javanese culture, the word Asyara - Asyura - Sura is used to substitute the name of the month of Muharram [2]. The substitution denotes the significance of 10 Muharram for Javanese Muslims. The festivity of Asyura on 10 Muharram done by Javanese in which Bubur Sura is served is a selamatan and commemoration for Imam Husain ra (the grandson of Prophet Muhammad saw) who is killed in the battle of Karbala on 10 Muharram 67 H/ $680 \mathrm{M}$ [3].

Javanese calls Muharram as the month of Sura; it is the new or first month in Islamic hijri calendar [4]. This month is considered special since people believe that it has something to do 
with magical or mystical things[5]. In Sura, people not only do religious activities such as fasting, praying, ablution, donating, and helping orphans but also do traditions such as selamatan, washing heirlooms, avoiding taboos, etc. These activities indicates that Sura is a special month.

A good character should be realized in daily life[6]. That good character is initiated by the knowledge on what good characters are. Therefore, a good character includes three inseparable aspects as moral knowing aspects, moral feeling aspects, and moral action aspects[7]. Moral knowing aspects are related to nurturing moral awareness, understanding moral values, considering other's perspectives, initiating moral reasoning, and involving moral in the process of decision making [8].

Character education values fostered in Indonesia come from religion, Pancasila, culture, and national education goals; they are being (1) religious, (2)honest, (3)tolerant, (4)discipline, (5)hard worker, (6)creative, (7)independent, (8)democratic, (9)curious; having (10) patriotism, (11) nationalism; being able to (12) appreciate achievement, (13)be communicative,(14) love peace, (15) be bibliophile, (16) have environmental care, (17) have social care, and (18) have responsibility [9]. In higher education, the character education is fostered through tri dharma perguruan tinggi (three pillars of higher education), organizational cultures, undergraduates' activities, and daily activities. Samin's character education values mentioned above are emphasized to be used as a source of character education that will be taught.

\section{METHOD}

The research on Sura traditional ceremony done by Samin people was done in Jepang, Margomulyo, Bojonegoro. This was descriptive qualitative research, a type of research in which objects were studied and the correlation between them were interpreted[10]. The data were collected through observation, interview, and document analysis. The data obtained from observation were related to daily activities involving either social behaviour activities, social status, Sura tradition, and culture. The interview involved the interviewer and seven interviewees who represented each group. Meanwhile, the documents analysed were books, scientific works, or texts relevant to the theme studied, and photos of Sura ceremony done by Samin people. The data analysis techniques were descriptive qualitative and interactive analysis that focused on meaning, description, and data placement in each context [11].

\section{RESULT AND DISCUSSION}

\subsection{The Practices of Sura Ceremony}

Selamatan done in Sura has strategic meaning for both Samin people and its elders. Selametan is the main teaching of Saminism. After observing and interviewing the elder of Samin, it is found out that Samin people determine the month of Sura by considering their belief on Javanese-Islamic components. We know that in Javanese calendar, Sura is the same with Muharram in Islamic calendar. Muharram is one of four sacred months beside Ramadhan (Pasa), Dzulqa'dah (Dulkaidah) and Dzulhijjah (Besar). Based on Javanese belief, Sura is a special month for doing mental and spiritual activities [12].

Sura ceremony is started by preparing offerings, tumpeng, and ubarampe as the symbols to show gratitude[13]. This is done in accordance to the birth of Samin elder Mbah Hardjo Kardi. The remarkable thing found in Sura ceremony is brokohan; a symbol of gratitude, prayer, Samin gathering, and teaching from Mbah Hardjo Kardi. Mbah Hardjo Kardi usually teaches people not to be jealous, envy, and greedy. The principle of selamatan is praying to the God. It 
is believed to be a communication means between people and the God. Solikin states that the month of Sura is a medium for Javanese people to pray for protection[14]. Sura ceremony is also believed as a momentum for Samin people to share and gather. It means that Sura ceremony combines the relationship among people as well as the relationship between people and God.

People face endless dialogue related to life and death with the God. They have mind, desire, and soul that should be equally used as a perfect creature. As a tradition that is always done to welcome Ramadan and Islamic New Year, Sura ceremony is prepared so that people can reflect their behavior in the previous year. People surely commit sins that should be wiped out before their death. Sura ceremony is Samin's (in Jepang, Margomulyo, Bojonegoro) local wisdom which aims to benefit each other and to welcome Muharram with a sincere heart. Hence, in a social context, Sura ceremony done by Samin people in Jepang, Margomulyo, Bojonegoro is a medium to foster social relationship and develop national identity. As a religious tradition, Sura ceremony is a spiritual recreation used to nurture the mind, desire, and soul. People then will realize their relationship with their God. Religious tradition done by Samin people in Jepang, Margomulyo, Bojonegoro is an initiative to develop awareness and to confess to the God so that they get protection, prosperity, and happiness in life.

\subsection{The Intentions of Sura Ceremony}

The intention of Sura ceremony that involves Islamic values done by Samin people is preserving ancestral heritage, showing gratitude to God, sharing with others, being blessed, praying for ancestral spirits, asking for God's protection, maintaining relationship, getting along well with others, being respectful, being spiritually mature, and considering social life. The principles of Sura ceremony for Samin people are ritual, individual, and social education. Selamatan teaches people about social solidarity and life principles which are not concerning on materialism but concerning on spiritualism. Therefore, Sura ceremony done by Samin in Jepang, Margomulyo, Bojonegoro has horizontal and vertical dialectical relationship that signify ritual, individual, and social piety. From Sura ceremony, people get to know the intention of the ritual which involves many Islamic values and teachings better.

The main and common intention of Sura ceremony done by Samin is showing gratitude and asking for protection, prosperity, safety, and happiness to the Almighty God[15]. As explained above; besides having spiritual values (read: dimension of Islamic culture), Sura ceremony comprises strategic social intention. There are at least three intentions of Sura ceremony done by Samin people. They are textual, contextual, and symbolic meaning. The textual meaning of Sura ceremony is realized on how people show their gratitude for the life given by the God. The contextual meaning itself has something to do with praying to ask for protection. Meanwhile, symbolic meaning is related to do selamatan in which offerings and ritual equipment are prepared (sharing with others).

\subsection{The Islamic Values of Sura Ceremony}

Sura ceremony aims at religious values. Based on the description and intention of Sura ceremony done by Samin, those values can be implemented in daily life. Religious values found in Samin through selamatan and offerings teach us how to be grateful for the life given by our Almighty God. People as creatures/servants should nurture their religious character. It is reflected by their attitude in doing religious practices. People should worship the God and be obedient to show their gratitude. With the religious values, people have better relationship with their God. Religious values found in Sura ceremony done by Samin are reflected through mantra and prayer. They pray to ask for protection. The mantra and prayer also tell people not 
to be weak and arrogant. Besides, people are expected to avoid committing sins.Brokohan or bancaan involved in Sura ceremony also indicates religious values since it becomes the symbol that people should share with others in any circumstances. Generally, Sura ceremony done by Samin is a combination of the relationship among people as well as the relationship between people and God.

Based on the above explanation, educational value involved in Sura ceremony is education related to adab. Adab refers to good things undergraduates must do and bad things they must not do in their daily life especially in the educational context [16]. Sura ceremony teaches them to show gratitude, avoid committing sins (ask for protection), share with others, live in harmony, be humble, and maintain the relationship with others as well as the God in educational context.

Adab involved in Sura ceremony is a normative discipline telling good things undergraduates must do and bad things they must not do [17]. In order to nurture adab, there are two Islamic teaching methods. The first is through command and advice telling that people should be obedient. The second is through prohibition. Muslims should not commit sins. Command and prohibition is the core of morality or adab. With the existence of command and prohibition, people are expected to learn adab first before being knowledgeable. Adab is a must-have thing for Muslims since it is strongly beneficial to maintain people's harmonious relationship either with others or with their God[18].

Based on the explanation, Sura ceremony and character education values can be implemented in higher education learning processes. Character education values can also be used as educational source, particularly those which are related to religious values and guidelines for higher education study[19]. A research conducted by Mumfangati et. al. identifies that local wisdoms owned by Samin people in Blora emerge several factors and social principles that underlie and reinforce character education for undergraduates [20]. Those factors include participation and social relationship, trust, social norm, adab, and proactive behavior. Based on the factors, undergraduates' character will be developed through Islamic values (Susanti, 2013: 480)[24]. Other factors that reinforce undergraduates' character are education obtained in family, educational, and community environment [21].

\section{CONCLUSION}

The religious values found in Sura ceremony done by Samin as character education in higher education have essential role. From the practices and intentions, it implies that Sura ceremony done by Samin involves religious values. It involves many character education values which are relevant to higher education curriculum and learning processes. Through higher education, especially in Bahasa Indonesia learning; religious character education found in Sura ceremony done by Samin people in Jepang, Margomulyo, Bojonegoro can be benefitted as learning sources and materials used in teaching learning processes.

\section{REFERENCES}

[1] Hidayati, NA., Herman J.W., Retno W., Suyitno. Ritual Animism and Religious on Sura Thanksgiving Ceremony of Samin Jepang Margomulyo Tribe Community. ICIGR. Advances in Social Science, Education and Humanities Research (ASSEHR), vol. 125, Pp. 348-353. 2017.

[2] Sayyid Sabiq. Fiqus Sunnah: Dalam pokok Bahasan Puasa Sunah Asyura, jilid 2, Cetakan Pertama, Pena Pundi Aksara, Jakarta. 2006. 
[3] Simuh. (1988). Mistik Islam Kejawen Raden Ngabehi Ranggawarsita: Suatu Studi Terhadap Serat Wirit Hidayat Jati. Jakarta: Universitas Indonesia Press.

[4] Nurudin (Editor). Agama Tradisional, UMM Press, Malang. 2002.

[5] Mulder, Niels. Mistisisme Jawa: Ideologi Di Indonesia, Cetakan pertama, LKiS, Yogyakarta. 2001.

[6] Skaggs, G., Bodenhorn, N. (2006). Relationships Between Implementing Character Education, Student Behavior, and Student Achievement. Journal of Advanced Academics , 8(1), 82-114.

[7] Lickona, Thomas. Educating for character. New York: Bantam Books. 1998.

[8] Thompson, L. Character Education and School Climate. Master, University of Minnesota Duluth, USA. 2010.

[9] Puskurbuk. Nilai-Nilai Pendidikan Karakter. Tim Kemendikbud. 2011.

[10] Miles, M.B. and A. M. Huberman. Qualitative Data Analysis A Sourcebook of New Methods, Sage, Beverly Hill. 1992.

[11] Moleong, Lexy J. Metode Penelitian Kualitatif Edisi Revisi, Bandung: Remaja Rosdakarya, 2013.

[12] Purwadi. Upacara Tradisional Jawa (Menggali Untaian Kearifan Lokal).Yogyakarta: pustaka pelajar. 2005.

[13] Yana, M.H. (2011). Tumpeng Ruwatan dan Falsafah Hidup Jawa. Jurnal Patrawidya. Seri penerbitan penelitian sejarah dan budaya. 11(3), Pp. 45-57.

[14] Sholikin, Muhammad. Misteri Bulan Sura Perspektif Islam Jawa. Yogyakarta: penerbit Narasi. 2010.

[15] Geertz, Clifford. The Religion of Java. Glencoe, Ill.,: Free Press, 1985.

[16] Bart Engelen, Alan Thomas, Alfred Archer \& Niels van de Ven. Exemplars and nudges: Combining two strategies for moral education. Journal of Moral Education, 47(3), 346365. 2018.

[17] Bachr, J. The Varieties of Character and Some Implications for Character Education. Journal of Youth and Adolescence, 46(6): 1153-1161. 2017.

[18] Suyatno, Jumintono, Pambudi, D. I., Mardati, A., \& Wantini (2019). Strategy of Values Education in the Indonesian Education System. International Journal of Instruction, 12(1), 607-624.

[19] Yusuf, Y. (2017). Integrasi Pendidikan Karakter Berbasis Qurani dan Kearifan Lokal Bugis. Jurnal Studi Agama dan Masyarakat, 11(2): 247-264.

[20] Mumfangati, Titi, dkk. Kearifan Lokal di Lingkungan Masyarakat Samin kabupaten Blora Jawa Tengah. Jarahnitra: Yogyakarta. 2004.

[21] Christen, Marcus. 2013. Comparing cultural differences with domain-specific differences of appreciating and understanding values. Journal of Moral Education, 47(3), 333-345. 2018. 